\title{
Preparation of Some Haloorganophosphonates(III) Compounds and Using as Flame Retardants for Epoxy and Unsaturated Polyester Resins
}

\author{
JALIL R. UGAL \\ Department of Chemistry, College of Science for Women, \\ University of Baghdad, Baghdad-Iraq \\ dr.jalilraheef@yahoo.com
}

Received 8 December 2014 / Accepted 12 December 2014

\begin{abstract}
Four compounds of haloorganophosphonates(III) ,namely; $\left(\mathrm{CH}_{3}\right)_{4} \mathrm{~N}\left[\mathrm{C}_{2} \mathrm{H}_{5} \mathrm{PCl}_{2} \mathrm{Br}\right]$ (I), $\left.\left(\mathrm{CH}_{3}\right)_{4} \mathrm{~N}\left[\mathrm{C}_{6} \mathrm{H}_{5} \mathrm{PCl}_{2} \mathrm{Br}\right](\mathbf{I I}),\left(\mathrm{CH}_{3}\right)_{4} \mathrm{~N}_{2} \mathrm{C}_{6} \mathrm{H}_{5} \mathrm{PCl}_{3}\right](\mathbf{I I I})$ and $\left.\left(\mathrm{CH}_{3}\right)_{4} \mathrm{~N}_{2} \mathrm{C}_{6} \mathrm{H}_{5} \mathrm{PBr}_{3}\right](\mathbf{I V})$ were prepared and characterized by FTIR spectroscopy, CHN analysis and conductive measurements . These compounds were used as flame retardants for epoxy and unsaturated polyester resins in the percentages of $(1,3,5$ and $7 \%$ ) according to three standard methods (ASTM). All of these compounds were effectively reduced the flammability and combustion of the resins. Additive IV was the most active one
\end{abstract}

Keywords: Organophosphonates(III), Flame retardant, Epoxy resin, Unsaturated polyester resins.

\section{Introduction}

Products manufactured from polymers find many uses and add greatly to the quality of modern day life. However, major problems arise because most of the polymers on which these materials are based are organic and thus flammable. In the UK alone some 800-900 deathly and roughly 15000 injuries result from fire each year ${ }^{1}$. Composite materials include those formed by the combination of two or more materials to achieve properties that are superior to those of its constituents. The design goal of a composite is to achieve a combination of properties that is not displayed by any single material and also to incorporate the best characteristics of each of the component materials ${ }^{2}$. Composite materials have been slowly replaced steel and aluminum alloys for a wide range of applications such as construction, transportation, aerospace, aircrafts, automobiles, ...etc ${ }^{3-4}$. Although these products have numerous advantages, they are poorly resistant to fire and organic solvents due to the nature of the polymeric matrix ${ }^{5}$. The reaction of these materials to fire was faced by developing many ways in order to reduce such reaction, e.g. modification of the polymer backbone or incorporation flame retardant into polymer ${ }^{6-7}$.

The addition of flame retardant improves the flame resistance, inhibiting the exothermic reaction in the gas phase via radical scavenging, then by reducing the energy feed back to the polymer surface. Another mechanism of the flame retardant work is by the formation of char as a thermal barrier at the surface of the condensed phase which blocks the liberation of gaseous fuel and prevents the fire back to the burning polymer ${ }^{8}$. 
Finally the epoxy and unsaturated polyester resins are any such a widespread use, especially with very interesting industrial applications due to their good properties and low cost.

\section{Experimental}

\section{Materials}

A- Polymers

1. Epoxy Resin, type (CY 223), hardener type (HY956) from Ciba Geiga Co.

2. Unsaturated polyester resin, hardener type (MEKP) from The United Arab Emirates.

B- Flame retardants

1. $\left(\mathrm{CH}_{3}\right)_{4} \mathrm{~N}\left[\mathrm{C}_{2} \mathrm{H}_{5} \mathrm{PCl}_{2} \mathrm{Br}\right]$

2. $\left(\mathrm{CH}_{3}\right)_{4} \mathrm{~N}\left[\mathrm{C}_{6} \mathrm{H}_{5} \mathrm{PCl}_{2} \mathrm{Br}\right]$

3. $\left(\mathrm{CH}_{3}\right)_{4} \mathrm{~N}\left[\mathrm{C}_{6} \mathrm{H}_{5} \mathrm{PCl}_{3}\right]$

4. $\left(\mathrm{CH}_{3}\right)_{4} \mathrm{~N}\left[\mathrm{C}_{6} \mathrm{H}_{5} \mathrm{PBr}_{3}\right]$

These additives were prepared according to methods reported by Jalil ${ }^{9}$, and characterized by FTIR spectroscopy, CHN elemental analysis, atomic absorption and conductivity measurements. Also their melting points were determined.

\section{Flame retardants measurement techniques}

Three techniques were employed to measure the efficiency of the flame retardants which are:

1. Limiting Oxygen Index (LOI):- According ${ }^{10}$ to ASTM-D 2863. LOI\% is calculated by the formula:

$$
\mathrm{LOI}=\frac{\mathrm{O}_{2} \%}{\mathrm{O}_{2} \%+\mathrm{N}_{2} \%} \times 100 \%
$$

Where $\mathrm{O}_{2}$ and $\mathrm{N}_{2} \%$ are the rate of flow in $\mathrm{cm}^{3} / \mathrm{s}$.

2. Rate of burning: According ${ }^{11}$ to ASTM-365. Using the formula:

$$
\mathrm{RB}=\frac{\mathrm{X}}{\mathrm{t}}
$$

Where $\mathrm{x}$ is the length of the sample (in $\mathrm{cm}$ ) that completely burn in time $(\mathrm{t})$ in minutes.

3. Maximum flame height $(\mathrm{H})$ : According $^{12}$ to the ASTM-D-3014.

The maximum flame height was measured by metal ruler in centimeter, after 10 second from starting the burning process.

\section{Preparation of samples}

The samples were prepared in $130 \times 130 \times 3 \mathrm{~mm}$ dimensions, three sheets of each sample were prepared using different percentages of the flame retardants $(1-7 \%)$ which were mixed carefully with the resins, then the hardener was added and in each case the cross linked polymer was casted in a mold.

\section{Results and Discussion}

\section{Characterization of compounds}

These compounds were characterized by FTIR spectroscopy, CHN elemental analysis, atomic absorption and conductivity measurements. Most characteristics IR peaks and elemental analysis data for these compounds are reported in Tables 1 and 2. The molar conductivities in $10^{-3} \mathrm{M}$ ethanol were found to be $20.3-59.8 \mu \mathrm{s} . \mathrm{cm}^{-1}$. The finding values revealed the formation of the aimed compounds. The products were white powders. 
Table 1. FTIR bands $\left(\mathrm{cm}^{-1}\right)$ of the prepared compounds

\begin{tabular}{|c|c|c|c|c|}
\hline Compound & $\gamma(\mathrm{P}-\mathrm{Cl})$ & $\gamma(\mathrm{P}-\mathrm{Br})$ & $\gamma(\mathrm{P}-\mathrm{C})$ & Others \\
\hline$\left(\mathrm{CH}_{3}\right)_{4} \mathrm{~N}\left[\mathrm{C}_{2} \mathrm{H}_{5} \mathrm{PCl}_{2} \mathrm{Br}\right]$ & 501 & 447,470 & 948 & $\begin{array}{l}\text { C-H } \\
\text { al.2958,2908 } \\
\text { C-N al.1400 } \\
\mathrm{CH}_{3}-1485 \\
\mathrm{C}-\mathrm{C} \text { al } 1296\end{array}$ \\
\hline$\left(\mathrm{CH}_{3}\right)_{4} \mathrm{~N}\left[\mathrm{C}_{6} \mathrm{H}_{5} \mathrm{PCl}_{2} \mathrm{Br}\right]$ & 493 & 424 & 1481 & $\begin{array}{l}\text { C-H } \\
\text { ar.3062,3016 } \\
\text { C-H al.1303 } \\
\text { C-N al. } 1400 \\
\text { Ph-M-S 744,694 }\end{array}$ \\
\hline$\left(\mathrm{CH}_{3}\right)_{4} \mathrm{~N}\left[\mathrm{C}_{6} \mathrm{H}_{5} \mathrm{PCl}_{3}\right]$ & 497 & - & 1473 & $\begin{array}{l}\text { C-H ar.3047 } \\
\text { C-N al.1388 } \\
\text { Ph-M-S } \\
744,694\end{array}$ \\
\hline$\left(\mathrm{CH}_{3}\right)_{4} \mathrm{~N}\left[\mathrm{C}_{6} \mathrm{H}_{5} \mathrm{PBr}_{3}\right]$ & - & 421 & 1473 & $\begin{array}{l}\text { C-H } \\
\text { ar.3054,3010 } \\
\text { C-H al.1301 } \\
\text { C-N al. } 1398 \\
\text { Ph-M-S 687,731 }\end{array}$ \\
\hline
\end{tabular}

Note: al =aliphatic; ar=aromatic; $\mathrm{Ph}-\mathrm{M}-\mathrm{S}=\mathrm{C}_{6} \mathrm{H}_{5}$-Monosubstitution

Table 2. Elemental analysis data of the prepared compounds.

\begin{tabular}{ccccccc}
\hline Compound & \multicolumn{6}{c}{ Elemental analysis, Calc., (Found) } \\
\cline { 2 - 7 } & $\mathrm{C} \%$ & $\mathrm{H} \%$ & $\mathrm{~N} \%$ & $\mathrm{Cl} \%$ & $\mathrm{Br} \%$ & $\mathrm{P} \%$ \\
\hline$\left(\mathrm{CH}_{3}\right)_{4} \mathrm{~N}\left[\mathrm{C}_{2} \mathrm{H}_{5} \mathrm{PCl}{ }_{2} \mathrm{Br}\right]$ & 25.26 & 5.96 & 4.91 & 24.91 & 28.07 & 10.87 \\
m.pt.332 $\mathrm{d}^{\circ} \mathrm{C}$ & $(24.93)$ & $(5.68)$ & $(4.75)$ & $(25.03)$ & $(27.85)$ & $(10.56)$ \\
$\left(\mathrm{CH}_{3}\right)_{4} \mathrm{~N}\left[\mathrm{C}_{6} \mathrm{H}_{5} \mathrm{PCl}{ }_{2} \mathrm{Br}\right]$ & 36.06 & 5.14 & 4.20 & 21.31 & 23.99 & 9.29 \\
m.pt. $140{ }^{\circ} \mathrm{C}$ & $(35.40)$ & $(4.78)$ & $(3.92)$ & $(20.80)$ & $(23.20)$ & $(8.70)$ \\
$\left(\mathrm{CH}_{3}\right)_{4} \mathrm{~N}\left[\mathrm{C}_{6} \mathrm{H}_{5} \mathrm{PCl}{ }_{3}\right]$ & 41.59 & 5.89 & 4.85 & 36.91 & - & 10.74 \\
$\mathrm{~m}_{4} \mathrm{pt} .285 \mathrm{~d}^{\circ} \mathrm{C}$ & $(41.00)$ & $(5.63)$ & $(4.65)$ & $(36.53)$ & - & $(9.98)$ \\
$\left(\mathrm{CH}_{3}\right)_{4} \mathrm{~N}\left[\mathrm{C}_{6} \mathrm{H}_{5} \mathrm{PBr}_{3}\right]$ & 28.43 & 4.02 & 3.31 & - & 56.87 & 7.34 \\
m.pt.307 d ${ }^{\circ} \mathrm{C}$ & $(28.15)$ & $(3.87)$ & $(3.09)$ & - & $(56.32)$ & $(7.15)$ \\
\hline
\end{tabular}

The chemical structures of the prepared haloorganophosphonates(III) compounds were suggested according to the analytical data to be a trigonal bipyramide geometry around $\mathrm{P}(\mathrm{III})$ ion as illustrated bellow:

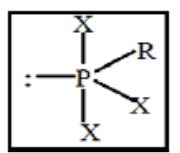

where $\mathrm{R}=$ alkyl or phenyl, $\mathrm{X}=\mathrm{Cl}$ or $\mathrm{Br}$.

\section{Flame retardation measurements}

The most important measured parameters are:

Limiting Oxygen Index (LOI): It is the percentage of oxygen gas in nitrogen-oxygen gas mixture, necessary to bring about the flame height of $5 \mathrm{~cm}$ minimum. Results of LOI are reported in Tables 3 and 4 indicated that all the additives were efficient to decrease 
flammability of epoxy and unsaturated polyester resins. They were so competent to stop combustion causing non burning at the higher percentages $(>5 \%)$. Their efficiency is following the order:

$$
\text { IV }>\text { III }>\text { II }>\text { I }
$$

This is due to the composition of the additives; i.e. $\left(\mathrm{CH}_{3}\right)_{4} \mathrm{~N}\left[\mathrm{C}_{6} \mathrm{H}_{5} \mathrm{PBr}_{3}\right]$ is more active than $\left(\mathrm{CH}_{3}\right)_{4} \mathrm{~N}\left[\mathrm{C}_{6} \mathrm{H}_{5} \mathrm{PCl}_{3}\right]$ because bromine is more active than chlorine to retard the flame, also the difference in the alkyl and phenyl groups found ${ }^{13}$.

Table 3. LOI for epoxy resin with different percentages of additives

\begin{tabular}{ccccc}
\hline$\%$ & 1 & 3 & 5 & 7 \\
Additives & & & & \\
\hline I & 21.58 & 22.97 & 24.31 & 25.29 \\
II & 22.17 & 23.41 & 24.65 & 25.93 \\
III & 22.61 & 24.03 & 25.72 & 26.84 \\
IV & 22.94 & 24.23 & 26.03 & 27.42 \\
\hline \multicolumn{5}{c}{ LOI for epoxy resin without additive $=19.7$}
\end{tabular}

Table 4. LOI for UPE resin with different percentages of additives

\begin{tabular}{ccccc}
\hline $\begin{array}{c}\% \\
\text { Additives }\end{array}$ & 1 & 3 & 5 & 7 \\
\cline { 1 - 5 } I & 22.13 & 23.75 & 24.81 & 26.07 \\
II & 23.05 & 24.60 & 25.52 & 26.73 \\
III & 23.21 & 24.83 & 25.75 & 26.90 \\
IV & 23.58 & 25.16 & 26.47 & 27.62 \\
\hline \multicolumn{5}{c}{ LOI for UPE resin without additive $=20.4$}
\end{tabular}

Figures 1 and 2 show how LOI increased with increasing the percentages of the additives proving their activity as flame retardants.

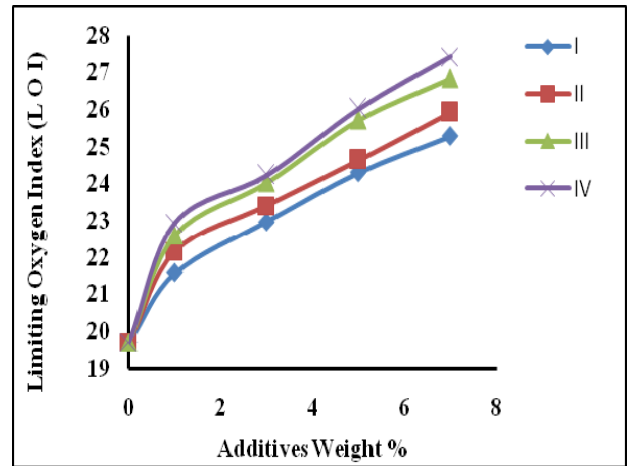

Figure 1. Relationship between Limiting Oxygen Index (LOI) and the percentages of additives for epoxy resin

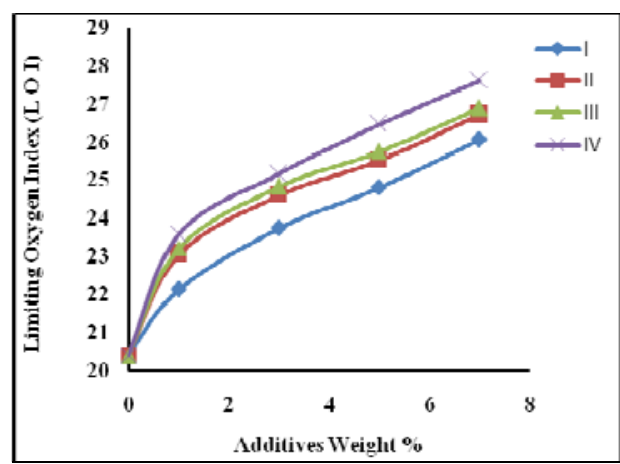

Figure 2. Relationship between Limiting Oxygen Index (LOI) and the percentages of additives for UPE resin

Rate of burning (RB): Measured results, Tables 5 and 6 clearly indicate the effectiveness of the flame retardants used in this work. The rate of burning is effectively decreased by increasing the weight percentage of used additives.

The order of efficiency shows that additive IV was the best for the same weight ratio compared with others.

$$
\text { IV }>\text { III }>\text { II }>\text { I }
$$


Table 5. Rate of burning for epoxy resin with different percentages of additives

\begin{tabular}{ccccc}
\hline$\%$ & 1 & 3 & 5 & 7 \\
Additives & & & & \\
\hline I & 1.30 & 1.05 & 0.85 & N.B \\
II & 1.28 & 0.96 & 0.64 & N.B \\
III & 1.10 & 0.75 & 0.50 & N.B \\
IV & 1.03 & 0.85 & 0.62 & N.B \\
\hline
\end{tabular}

Rate of burning for epoxy resin without additives $=1.95, N . B=$ not burning

Table 6. Rate of burning for UPE resin with different percentages of additives

\begin{tabular}{ccccc}
\hline$\%$ & 1 & 3 & 5 & 7 \\
Additives & & & & \\
\hline I & 1.20 & 0.95 & 0.70 & N.B \\
II & 1.15 & 0.89 & 0.42 & N.B \\
III & 1.09 & 0.78 & 0.31 & N.B \\
IV & 1.05 & 0.73 & N.B & N.B \\
\hline Rate of burning for UPE resin without additives $=1.44$
\end{tabular}

Figures 3 and 4 reveal that $\mathrm{RB}$ is inversely proportional to the increase in the percentages marking the good effect of the flame retardants.

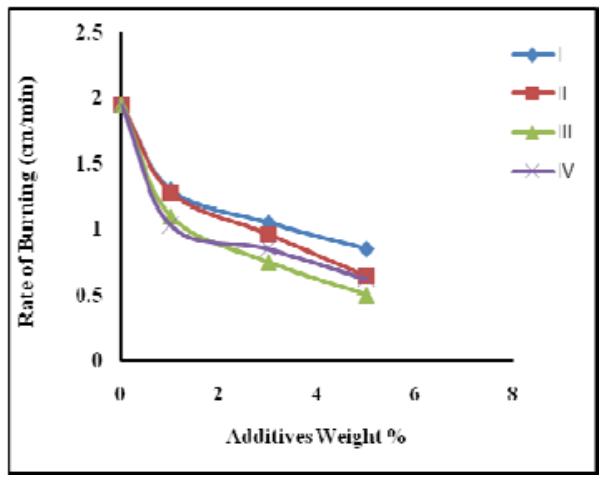

Figure 3. Relationship between Rate of Burning (R.B) and the percentage of the additives for epoxy resin

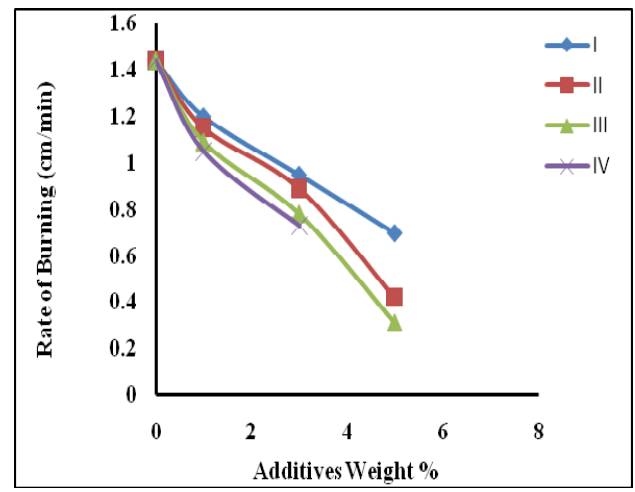

Figure 4. Relationship between Rate of Burning (R.B) and the percentage of the additives for UPE resin

Maximum flame height $(H)$ : Flame heights during the burning were also monitored using different weight ratio of the additives. The results listed in Tables $7 \& 8$ refer that $\mathrm{H}$ is gradually decreased as the $\%$ additive increased for the two resins with all types of the flame retardants.

Table 7. Maximum flame height $(\mathrm{H})$ for epoxy resin with different percentages of additives

\begin{tabular}{|c|c|c|c|c|}
\hline Additives $\%$ & 1 & 3 & 5 & 7 \\
\hline I & 9.5 & 7.0 & 5.5 & - \\
\hline II & 9.0 & 6.5 & 5.0 & - \\
\hline III & 8.0 & 6.0 & 4.5 & - \\
\hline IV & 6.0 & 4.2 & 2.0 & - \\
\hline
\end{tabular}


Table 8. Maximum flame height $(\mathrm{H})$ for UPE resin with different percentages of additives

\begin{tabular}{cccccc}
\hline \multicolumn{2}{c}{$\%$} & & 1 & 3 & \multicolumn{2}{c}{5} \\
Additives & & & & \\
\hline I & 10.0 & 7.5 & 6.0 & - \\
II & 9.5 & 6.0 & 4.5 & - \\
III & 8.0 & 5.0 & 3.5 & - \\
IV & 6.5 & 3.2 & - & - \\
\hline \multicolumn{5}{c}{ H for UPE without additives $=14$}
\end{tabular}

Again the effectiveness of these additives is in agreement with the results obtained in case of LOI and RB mentioned earlier; the most active FR is that gives the lowest H. The order of effectiveness is:

$$
\text { IV }>\text { III }>\text { II }>\text { I }
$$

The results obtained in all measurements indicate that these additives can effectively reduce the flammability of the polymers. Figures 5 and 6 express the relationship between $\mathrm{H}$ and the percentages of additives for epoxy and unsaturated polyester resins respectively.

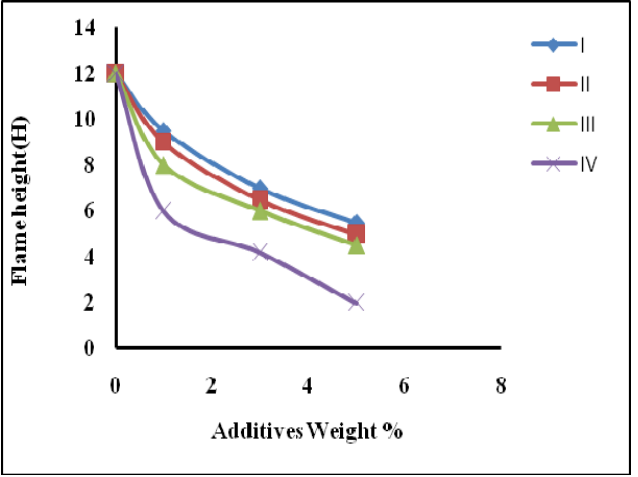

Figure 5. Relationship between Flame Height $(\mathrm{H})$ and the percentage of the additives with epoxy resin

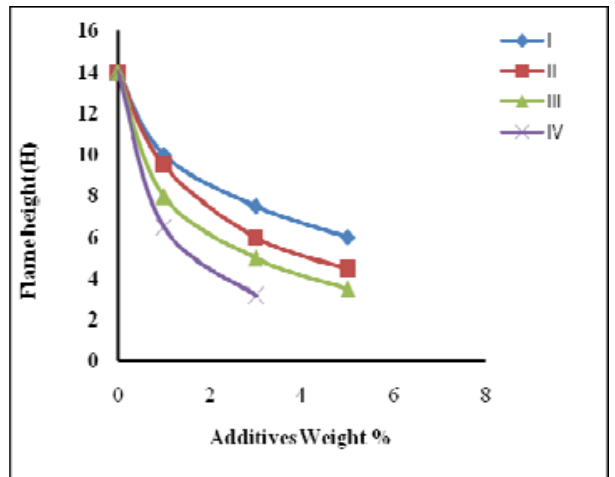

Figure 6. Relationship between Flame Height $(\mathrm{H})$ and the percentage of the additives with UPE resin

The additives can also interfere with the chain reaction usually occurs in the vapor phase during the oxidation process; i.e. can terminate the free radicals, $\left(\mathrm{OH}^{\circ}, \mathrm{O}^{\circ}, \mathrm{OOH}^{\circ}, \mathrm{OR}^{\circ}, \ldots .\right.$. etc.) as a chain carrier and transfer them to non radical species, which is clearly appear when increasing the percentages of the flame retardants causing non burning.

\section{Conclusions}

The four haloorganophosphonates(III) compounds in this work were successfully prepared and used as flame retardants for epoxy and unsaturated polyester resins. They were very efficient causing to stop combustion of resins in their higher percentages (7\%) used here.

\section{References}

1. Horroks A R and Price D, "Fire retardant materials", $2^{\text {nd }}$ Ed., CRC Press LLC, Cambridge, England, 2001, p.1.

2. Hinduja S, "Proceedings of the $34^{\text {th }}$ International Matador Conference", SpringerVerlag, London Limited, 2004, p. 147.

3. Mourites A P and Gibson A G, Fire properties of Polymer composites, Springer, Dordrecht, The Netherlands, 2006. 
4. Bourbigot S and Flambard X, Fire Mater., 2002, 26, 155-168; DOI: 10.1002/fam.799

5. Caroline G, Gaella F and Serge B, Material, 2010, 3, 4476-4499; DOI: 10.3390/ma3084476

6. Chen D Q, Wang Y Z and Hu X P, Polym Degrad Stab., 2005, 88, 349; DOI:10.1016/j.polymdegradstab.2004.11.010

7. Choi J, Yee A F and Laine R M, Macromolecules, 2003, 36, 5666-5682; DOI: $10.1021 / \mathrm{ma} 030172 \mathrm{r}$

8. Zammarano M, Thermoset Fire retardant nanocomposites in flame retardant polymer Nanocomposites, John Wiley and Sons; Hoboken, NJ, USA, 2007, 235.

9. Ugal, J.R, Jha N K and Pankaj S, Indian J Chem., 1993, 32A, 71

10. Annual Book of ASTM, Part 19, 1985; http://www.opbpak.com/ASTM/D2863-00.pdf

11. Annual Book of ASTM, Part 35, 1983; http://file.yizimg.com/424653/2013112613001841.pdf

12. Annual Book of ASTM, Part 35, Plastic General Test Method, 1981; http://www.opbpak.com/ASTM/D3014-04.pdf

13. Jha N K, Misra M C and P Bajaj P, Macromol Chem Phys., 1984, C24 (1), 69. 